\author{
DARIUSZ JAROSZ \\ Instytut Historii Polskiej Akademii Nauk \\ GRZEGORZ MIERNIK \\ Instytut Historii Uniwersytetu Jana Kochanowskiego w Kielcach
}

\title{
POWÓDŹ ROKU 1947. Z BADAŃ NAD KONTEKSTAMI KLECSK ELEMENTARNYCH W POLSCE PO II WOJNIE ŚWIATOWEJ
}

W Polsce niszczącą siłę anomalii pogodowych i klęsk elementarnych mogliśmy poznać ostatnio przede wszystkim podczas „powodzi tysiąclecia” w lipcu 1997 r. Na temat jej przebiegu i wielorakich skutków dysponujemy bogatą i różnorodną dokumentacją źródłowa. Gdy jednak próbujemy umieścić to, co się wówczas stało, w szerszym kontekście historycznym, stajemy przed niełatwym wyzwaniem. Jakie były największe klęski żywiołowe, które nawiedziły Polskę wcześniej? Co wiadomo o ich zasięgu i skutkach? - oto najważniejsze pytania, na które trudno znaleźć wyczerpująca (a czasami jakąkolwiek) odpowiedź w opracowaniach historycznych. O ile bowiem w literaturze światowej historia klimatu, w tym jej społeczne konteksty, były przedmiotem wielu opracowań ${ }^{1}$, o tyle $\mathrm{w}$ Polsce badania takie sa słabo rozwinięte, prowadzone przez waską grupę specjalistów klimatologów, zajmujacych się ustalaniem zmienności temperatur, opadów atmosferycznych, zachmurzenia, pokrywy śnieżnej itp. ${ }^{2} \mathrm{O}$ tym, co stanowi o „ludzkim” wymiarze tych zjawisk, dowiadujemy się z tych prac niewiele.

\footnotetext{
${ }^{1}$ Zob. m.in.: E. Le Roy Ladurie, Histoire humaine et comparée du climat, Paris 2005; tenże, Histoire du climat depuis l'an mil, Paris 1967; Oxford Handbook of Climate Change and Society, red. J.S. Dryzek, R.B. Norgaard, D. Schlosberg, Oxford 2011; Climate Extremes and Society, red. H.F. Diaz, R.J. Murnane, Cambridge 2008; W. Behringer, A Cultural History of Climate, Cambridge 2010.

${ }^{2}$ Zob. m.in.: A. Woś, Klimat Polski, Warszawa 1999; tenże, Klimat Polski w drugiej połowie XX wieku, Poznań 2010; Klimat i bioklimat miast, red. K. Kłyś, Łódź 1995; 200 lat regularnych pomiarów i obserwacji meteorologicznych w Gdańsku, red. M. Miętus, J. Filipiak, A. Wyszkowski, Warszawa 2007. Wiele ciekawych informacji i studiów dotyczących zmienności klimatu w Polsce od połowy XX w. można znaleźć w „Pracach
} 
Te ogólne konstatacje dotyczą również historii Polski po II wojnie światowej, w tym badań nad powodziami. Nieliczne opracowania na ten temat koncentruja się na zjawiskach meteorologicznych, które je wywoływały, oraz szacunku strat przez nie spowodowanych ${ }^{3}$. Nawet jeżeli powstawały prace mające charakter monograficzny, to polityczne, gospodarcze i społeczne aspekty powodzi były w nich zwykle pomijane, względnie analizowane w taki sposób, że poczynione ustalenia nie udzielają odpowiedzi na wiele najistotniejszych pytań ${ }^{4}$.

Zanim takie wyczerpujace prace powstana, warto pokusić się o podjęcie tematu w ujęciu wycinkowym. Tak należy traktować niniejszy szkic, dotyczący niektórych kontekstów powodzi z 1947 r. Jest on pierwszą próbą zmierzenia się z materią nowa, co wymagało dość skomplikowanych poszukiwań badawczych, szczególnie archiwalnych. Wynikało to ze znacznego rozproszenia struktur biurokratycznych zajmujacych się tą problematyka. Cennym źródłem okazała się również prasa, zwłaszcza regionalna, z lat 1946-1947.

\footnotetext{
i Studiach Geograficznych", wydawanych przez Wydział Geografii i Studiów Regionalnych Uniwersytetu Warszawskiego. Do nielicznych prac historycznych pokazujacych niektóre aspekty ekstremów klimatycznych w Polsce należą m.in.: O. Muszkat, Ekstrema klimatyczne na ziemiach polskich $w$ czasach piastowskich wedtug źródet historycznych, „Prace Historyczno-Archiwalne” 23, 2011; T. Dunin-Wassowicz, Klimat jako czynnik kształtujacy środowisko człowieka $w$ średniowieczu, w: Problemy nauk pomocniczych, t. 3, Katowice 1974, s. 17-35; Wyjatki ze źódet historycznych o nadzwyczajnych zjawiskach hydrologiczno-meteorologicznych na ziemiach polskich w wiekach od X do XVI, red. A. Rojecki, Warszawa 1965; K. Wnęk, Dzieje klimatu Galicji w latach 1848-1913. Wptyw zjawisk meteorologicznych na społeczno-gospodarczy rozwój Galicji, Kraków 1999.

${ }^{3}$ Zob. m.in.: W. Mamak, Z. Tyszka, Statystyka szkód powodziowych w Polsce ze szczególnym uwzględnieniem lat ostatnich, „Gospodarka Wodna” 1954, nr 4, s. 142 -143; Ekstrema pogodowe w Polsce: obserwacje, pomiary, prognozy, red. M. Maciejewski, M.S. Ostojski, Warszawa 2008; J. Michalczewski, H. Mycielska, Meteorologiczne przyczyny powodzi w Polsce w lipcu 1960 roku, Warszawa 1963; J. Stachý, Wezbrania rzek polskich w latach 1951-1990, Warszawa 1996.

${ }^{4}$ Powódź w roku 1960. Materiaty monograficzne, red. S. Gudzio, Warszawa 1967; Powódź w lipcu 1970 r.: monografia, red. K. Fiedler, S. Ihnatowicz, A. Stolarska, Warszawa 1972; Powódź na Opolszczyźnie w sierpniu 1977 roku. Materiaty monograficzne, red. A. Melich i in., Opole 1979. Podstawowe, bardzo skrótowe informacje o powodziach w Polsce w ujęciu historycznym można odnaleźć w pracy Zarys monografii powodzi $w$ Polsce w 40-lecie Głównego Komitetu Przeciwpowodziowego, Warszawa 1988, oraz w szkicu Z. Tyszki, Powodzie $w$ Polsce $i$ ochrona przed nimi $w$ zarysie historycznym, „Gospodarka Wodna” 1954, nr 4, s. 144-146. Różnorodne konteksty powodzi w powojennej Polsce zawierają natomiast: popularnonaukowy artykuł Bartłomieja Grudnika (Zimy stulecia w PRL, „Mówią Wieki” 2003, nr 2, s. 34-37) oraz niektóre referaty wygłoszone na konferencji „Klęski elementarne na ziemiach polskich i ich skutki gospodarcze i społeczne” (Stary Gierałtów, 17-19 V 2013).
} 
W szkicu tym chcieliśmy przybliżyć się do odpowiedzi na pytania, jak owa powódź przebiegała, jak wpływała na gospodarkę i życie codzienne Polaków oraz jak była traktowana przez ówczesne władze państwowe. Próba takiej analizy, przy świadomości wszystkich jej niedoskonałości i początkowego stadium podjętych badań, idzie w kierunku kulturowych i społecznych interpretacji historii klimatu, rozwijanych z dużym powodzeniem w historiografii światowej.

\section{Prolegomena: przed powodzią - mrozy}

Przesłanką wskazującą na możliwość wystapienia wiosennej powodzi roztopowej w 1947 r. były zjawiska klimatyczne, jakie zaobserwowano zimą 1946/1947. Wyjątkowo silne mrozy, jakie skuły Polskę od połowy listopada 1946 r., utrzymywały się do połowy marca 1947. Okres kulminacji mrozów zaczął się w połowie stycznia i trwał do połowy lutego. Obfite opady śniegu, które początkowo objęły województwa: łódzkie, gdańskie, warszawskie, wrocławskie, śląskie, krakowskie i rzeszowskie (pokrywa śnieżna wynosiła tam miejscami $1,5 \mathrm{~m}$ ), od połowy lutego do połowy marca objęły cały kraj. Pojawiły się ostre i zimne wiatry, zwłaszcza w województwach północnych i zachodnich, które zwiały śnieg z pól wyżej położonych, co miało szczególnie negatywny wpływ na wegetację zbóż

Polska nie była zresztą wówczas pod tym względem wyjątkiem. W styczniu i lutym 1947 r. mrozy i śniegi sparaliżowały transport drogowy i rzeczny w niemal całej Europie. Wyjątkowo trudna była sytuacja w strefach okupacyjnych Niemiec: nastapiły ograniczenia dostaw prądu, co pociagało za soba zamykanie fabryk. Na skutek silnych mrozów Bukareszt w ciagu kilku dni pozbawiony był dostaw mięsa i chleba. Morze Czarne zamarzło na przestrzeni około $8 \mathrm{~km}$ od brzegu ${ }^{6}$. Mrozy powodowały zerwanie na wiele dni łączności telefonicznej nie tylko wewnętrznej, ale również międzynarodowej (Rumunia). W Wielkiej Brytanii koleje ograniczyły ruch pasażerski, statki miały problemy z transportem węgla. Wiele miejscowości zostało odciętych od świata. $\mathrm{Na}$ tym tle doszło zreszta do kryzysu politycznego ${ }^{7}$. Niskie temperatury i śnieg pojawiły się nawet na Florydzie; sparaliżowana została komunikacja kolejowa, samochodowa i lotnicza w $\mathrm{USA}^{8}$.

${ }^{5}$ Statystyka rolnicza 1947, Warszawa 1949, s. 6 n.

${ }^{6}$ [b.a.], Mrozy $w$ Europie paralizuja życie, „Gazeta Ludowa” 1947, nr 11; [b.a.], Mróz i burze śnieżne, „Głos Wielkopolski” 1947, nr 41.

${ }^{7}$ [b.a.], Kryzys węglowy w Wielkiej Brytanii, „Trybuna Robotnicza” 1947, nr 46.

8 Tamże. 
W wypadku Polski mrozy miały dotkliwe skutki gospodarcze. Według szacunków GUS-owskich korespondentów rolnych wymarzło 44\% zasiewów pszenicy, $22 \%$ żyta, $62 \%$ rzepaku i 39\% koniczyny. Część zasiewów ozimin musiano zaorać9. Wymarzła znaczna ilość zakopcowanych ziemniaków ${ }^{10} \mathrm{i}$ - co należy uznać za jedyny pozytywny efekt niskich temperatur - myszy polnych ${ }^{11}$.

Między 27 I 1947 r. a drugą dekadą marca ruch statków w portach bałtyckich zamarł lub był minimalny ${ }^{12}$, co - zważywszy na fakt, że droga morską docierała do Polski większość towarów z importu - odbiło się na funkcjonowaniu gospodarki i na aprowizacji ${ }^{13}$. Brak dostaw bawełny spowodował przestoje w fabrykach włókienniczych w Częstochowie ${ }^{14}$. Do Polski nie dotarły nawozy sztuczne z Wielkiej Brytanii $^{15}$ i konie z USA ${ }^{16}$, a węgiel z Polski nie mógł być dostarczony do zachodnich kontrahentów ${ }^{17}$. Zaprzestanie połowów na skutym lodem

${ }^{9}$ Statystyka rolnicza..., s. $6 \mathrm{n}$.

${ }^{10}$ Archiwum Akt Nowych w Warszawie (dalej: AAN), Ministerstwo Ziem Odzyskanych (dalej: MZO), sygn. 193 (mk. B-5297), Sprawozdanie sytuacyjne wojewody poznańskiego za grudzień 1946, k. 43; AAN, MZO, sygn. 190 (mkf. B-5294), Sprawozdanie Wojewody Pomorskiego za luty 1947, k. 103; AAN, MZO, sygn. 248 (mkf. B-5353), Sprawozdanie sytuacyjne wojewody wrocławskiego za III kwartał 1947; AAN, Ministerstwo Administracji Publicznej (dalej: MAP), sygn. 55 (mkf. B-746), Sprawozdanie kwartalne z działalności Wojewody Gdańskiego za I kwartał 1947, k. 11; AAN, MAP, sygn. 48 (mkf. B-739), Miesięczne sprawozdanie sytuacyjne wojewody białostockiego za kwiecień 1947, k. 59. Podobną opinię zob. J. Kaliński, Wptyw sytuacji rynkowej na warunki bytowe ludności (lipiec 1946 - grudzień 1948), KH 76, 1969, nr 2, s. 322.

${ }^{11}$ AAN, Centralny Urząd Planowania (dalej: CUP), sygn. 390, Sprawozdanie o sytuacji gospodarczej w Polsce, marzec 1947, k. 62-65; AAN, MZO, sygn. 189 (mkf. B-5293), Sprawozdanie Wydziału Społeczno-Politycznego Urzędu Wojewódzkiego Olsztyńskiego za kwiecień 1947, k. 73 n. Zob. też: J. Parnas, Sprawa doniosła i pilna. Walka z chorobami zwierzat $i$ szkodnikami roślin, „Głos Ludu” 1947, nr 58.

12 [b.a.], Port gdański otwarty, ale nie ma do niego dostepu, „Dziennik Bałtycki” 1947, nr 42; [b.a.], Praca portów w Gdyni i Gdańsku w lutym 1947, „Dziennik Bałtycki" 1947, nr 72; [b.a.], Port gdański znowu czynny. "Jermak" otwiera ruch $w$ porcie, „Dziennik Bałtycki” 1947, nr 78; [b.a.], Battyk w okowach lodu, „Kurier Szczeciński” 1947, nr 47; [b.a.], Lody z portu sptynęty, „Kurier Szczeciński” 1947, nr 81.

${ }^{13}$ E. Kwiatkowski, Diariusz 1945-1947, przygotował do druku, przypisami oraz biografią E. Kwiatkowskiego poprzedził Z. Michalski, Gdańsk 1988, s. 259-260.

${ }^{14}$ AAN, CUP, sygn. 390, Sprawozdanie o sytuacji gospodarczej w Polsce, marzec 1947, k. 61-62; tamże, Sprawozdanie o sytuacji gospodarczej w Polsce, luty 1947, k. 43.

15 [b.a.], Okręty uwięzty w lodach, „Trybuna Robotnicza” 1947, nr 46.

${ }^{16}$ AAN, MZO, sygn. 185 (mkf. B-5289), Sprawozdanie sytuacyjne wojewody olsztyńskiego za miesiąc luty 1947, k. 6.

${ }^{17}$ M., $Z$ morzem nie ma żartów, „Gazeta Ludowa” 1947, nr 42. 
Bałtyku oznaczało brak świeżych ryb na rynku krajowym ${ }^{18}$. Aprowizację i zaopatrzenie fabryk $\mathrm{w}$ surowce utrudniały również problemy komunikacji kolejowej i samochodowej ${ }^{19}$. Z tych przede wszystkim powodów między styczniem a majem $1947 \mathrm{r}$. utrzymywała się tendencja wzrostowa wolnorynkowych cen artykułów żywnościowych ${ }^{20}$.

„Syberyjskie mrozy” i ogromne opady śniegu paraliżowały również komunikację miejska, a nawet ruch pieszy ${ }^{21}$. Usiłowano $-\mathrm{z}$ wielkimi trudnościami - zaangażować mieszkańców miast do uprzątania śniegu $\mathrm{z}$ ulic i torów kolejowych ${ }^{22}$.

Co prawda nie udało się ustalić, ile ofiar śmiertelnych pochłonęła polska mroźna zima 1946/1947, ale wiadomo, że wywołane przez nią trudności pogorszyły nastroje społeczne. $Z$ powodu braku opału zamykano szkoły i urzędy, pojawiły się problemy w funkcjonowaniu szpitali, sanatoriów, prewentoriów i domów leczniczych ${ }^{23}$. W lutym 1947 r. w Polsce szalała epidemia grypy, a apteki były oblężone przez ludzi poszukujących chininy i etopiryny ${ }^{24}$. Z powodu mrozów dochodziło do katastrof budowlanych $\mathrm{w}$ zrujnowanych, ale zamieszkanych kamienicach

18 [b.a.], Kutry rybackie w okowach lodowych, „Dziennik Bałtycki” 1947, nr 9; [b.a.], Sytuacja w rybołówstwie morskim, „Dziennik Bałtycki” 1947, nr 11; [b.a.], Rybołówstwo morskie unieruchomione przez lody i mrozy, „Dziennik Bałtycki” 1947, nr 44; [b.a.], Martwy sezon w rybołówstwie morskim, „Dziennik Bałtycki” 1947, nr 62.

${ }^{19}$ AAN, CUP, sygn. 390, Sprawozdanie o sytuacji gospodarczej w Polsce, luty 1947, k. 43.

${ }^{20}$ AAN, CUP, sygn. 390, Sprawozdanie o sytuacji gospodarczej w Polsce, marzec 1947, k. 71; tamże, Sprawozdanie o sytuacji gospodarczej w Polsce, luty 1947, k. 40; tamże, Sprawozdanie o sytuacji gospodarczej w Polsce, kwiecień 1947, k. 90-92; tamże, Sprawozdanie o sytuacji gospodarczej w Polsce, maj 1947, k. 123.

${ }^{21}$ [b.a.], Czas nagli. Tylko zdecydowana akcja zwalczy skutki śnieżycy $w$ Warszawie, „Życie Warszawy” 1947, nr 57; [b.a.], Powrotna fala śniegów paraliżuje komunikację miejska, „Głos Ludu” 1947, nr 71; [b.a.], Mróz i śnieg klęska, „Gazeta Ludowa” 1947, nr 42.

${ }^{22}$ Zob. m.in.: [b.a.], Cała ludność stolicy musi wziqć udział $w$ akcji odśnieżania miasta, „Życie Warszawy” 1947, nr 61; [b.a.], Warszawa może znaleźć się pod woda. Brak inicjatywy, organizacji i rak do pracy, „Życie Warszawy” 1947, nr 65; [b.a.], Do walki ze śniegiem wzywa Rada Zwiazków Zawodowych, „Życie Warszawy” 1947, nr 66; [b.a.], Brak kilofów do dragów. Apel Komitetu Odśnieżania Warszawy, „Życie Warszawy" 1947, nr 66; [b.a.], Warszawa traci cierpliwość! Kto wreszcie zajmie się uprzatnięciem śniegu, „Życie Warszawy” 1947, nr 71; AAN, MAP, sygn. 107 (mkf. B-798), Sprawozdanie kwartalne wojewody pomorskiego za I kwartał 1947 r., k. 62.

${ }^{23}$ AAN, MAP, sygn. 115 (mkf. B-806), Sprawozdanie z działalności Urzędu Wojewódzkiego Poznańskiego za czas od 1 I 1947 do 31 III 1947, k. 59; [b.a.], Zakopane bez opatu, „Robotnik” 1947, nr 34.

${ }^{24}$ [b.a.], Grypa szaleje w Warszawie, „Życie Warszawy” 1947, nr 41; [b.a.], Mróz $i$ śnieg...; [b.a.], Mróz, śnieg i grypa. Szkoty nieczynne, robotnicy oczyszczaja tory (korespondencja wtasna „Głosu Ludu”), „Głos Ludu” 1947, nr 46. 
miejskich. Niebezpieczeństwo zamarznięcia sieci wodociagowej wymuszało odcięcie wielu budynków mieszkalnych od dostaw wody ${ }^{25}$.

Wskazane skutki mrozów z pewnością nie wyczerpuja ich katalogu. Bardzo niskie temperatury, przeplatane krótkimi okresami odwilży, wraz z obfitymi opadami śniegu stworzyły wprost idealne warunki klimatyczne do powodzi, jaka dotknęła Polskę wiosną $1947 \mathrm{r}$.

\section{Polska powódź 1947 r.}

\section{Przyczyny}

Autorzy raportu Sekcji Technicznej Głównego Komitetu Przeciwpowodziowego ${ }^{26}$ z kwietnia 1947 r. wskazywali na trzy najważniejsze jej przyczyny klimatyczne.

Pierwsza była natury ogólnej i wynikała z położenia geograficznego: w Polsce z tego powodu, że ocieplenie następuje zazwyczaj wcześniej na południu niż na północy, lód nie ma swobodnego odpływu i gromadzi się, tworząc mniejsze lub większe zatory w korytach rzek, zaś powstające poza zatorami spiętrzenia wody powoduja wylewy poza wały, ich przerywanie i zalewanie przybrzeżnych obszarów, często zamieszkanych. W 1947 r. pierwsze ruszenie lodów na karpackich dopływach Wisły nastapiło 24 lutego. W Warszawie Wisła ruszyła 20 marca, przy ujściu 23 marca, zaś Odra przy ujściu pod Szczecinem dopiero 29 marca. Odstęp czasu między ruszeniem lodów w górze i dole rzek wyniósł jeden miesiąc. Na Sanie jednego dnia temperatura wynosiła: w Zagórzu plus 8 st. C, w Przemyślu - 0 st. C , a w Sandomierzu minus 20 st. C; w tej sytuacji musiały powstać groźne zatory. Podobne zjawiska pojawiły się w innych miejscach.

Druga przyczyną powodzi była wskazana już wyjątkowo sroga zima i grubość lodu (40-60 cm, a nierzadko $1 \mathrm{~m}$ ) oraz spływ potężnych jego mas przy dużej szybkości nurtu rzek i ich wysokich stanach.

Trzecia przyczyna wymieniona w cytowanym dokumencie był niekorzystny układ opadów śniegu, których największe nasilenie przypadło

${ }^{25}$ [b.a.], Ziemia zamarzła na $170 \mathrm{~cm}$ głęboko. 90 domów bez wody, „Życie Warszawy” 1947, nr 48; [b.a.], Runęty 4 pietra na ul. Hożej 14. Straż Ogniowa ratuje zagrzebanego, „Życie Warszawy” 1947, nr 19.

${ }^{26}$ Po trudnej akcji przeciwpowodziowej w czasie wiosennego spływu lodów w 1946 r. na dolnej Wiśle uchwałą Prezydium Komitetu Ekonomicznego Rady Ministrów z 19 lipca tego roku powołany został stały organ państwowy pod nazwą Główny Komitet Przeciwpowodziowy (w strukturze Ministerstwa Administracji Publicznej) oraz komitety powodziowe działajace przy prezydiach rad narodowych. 
na połowę lutego i połowę marca. W czasie bezpośrednio poprzedzającym spływ lodu śniegi nie mogły wsiąknąć w ziemię i w konsekwencji podniosły stany wody ${ }^{27}$.

Wydaje się, że wskazane anomalie klimatyczne były najważniejszymi, ale nie jedynymi powodami powodzi z lutego-marca $1947 \mathrm{r}$. Warto pamiętać, że na jej przebieg, w tym skalę strat, miały wpływ zaniedbania, które były skutkiem wojny. Chodzi przede wszystkim o niekonserwowane, częściowo zdemolowane w wyniku działań zbrojnych wały przeciwpowodziowe, przepompownie wody i urządzenia melioracyjne. Ponadto w nurtach wielu rzek znajdowały się metalowe części zniszczonych mostów oraz innych konstrukcji. To one również, poza innymi przyczynami, utrudniały swobodny spływ lodów, których napór na wiele prowizorycznych, nierzadko drewnianych mostów kolejowych i drogowych powodował ich zawalenie mimo ofiarnych prób obrony przez cywilów i wojsko. Np. zimą 1946/1947 pod mostem Poniatowskiego leżało w nurcie Wisły około 2500 ton konstrukcji i 1500 ton „zbrojonej nawierzchni”, w okolicach mostu Kierbedzia - 1000 ton takich materiałów, a koło Mostu Drogowego w okolicach Cytadeli 600 ton. Łaczny koszt ich wydobycia szacowano na $100 \mathrm{mln} \mathrm{zt}^{28}$. Jak donosił Główny Komitet Przeciwpowodziowy w końcu listopada 1946 r., ważniejszym mostom na Wiśle: w Puławach, Dęblinie, Modlinie, Toruniu, Grudziądzu i Tczewie - gdzie długotrwałe roboty trzeba było odroczyć do wiosny 1947 r. - zapewniono ochronę wojskową (jak się miało okazać, nie zawsze skuteczna). O ile na Wiśle stan zabezpieczeń powodziowych miał ulegać wówczas poprawie, to na Odrze, wskutek „10-krotnie większej ilości zwalisk mostów i zaniedbania intensywnej akcji w pracach nad ich wydobyciem" - sytuację na wypadek powodzi oceniano jako katastrofalna. „Składa się na to na Odrze i kwestia graniczna, która praktycznie wpływa na «bezpańskość» mostów pozostajacych na lewym brzegu Odry pod okupacją radziecka"29. Obawy Komitetu w dużej części potwierdziły wydarzenia najbliższych miesięcy.

${ }^{27}$ AAN, Ministerstwo Pracy i Opieki Społecznej (dalej: MPiOS), sygn. 271, Główny Komitet Przeciwpowodziowy, Sekcja Techniczna, Sprawozdanie techniczne z przebiegu powodzi wiosennej 1947 roku, Warszawa, 14 IV 1947, k. 66. Taka sama argumentacja: W. Balcerski, Powódź wiosenna 1947 roku, „Gospodarka Wodna” 1947, nr 2, s. $46-49$.

${ }^{28}$ AAN, Ministerstwo Rolnictwa i Reform Rolnych (dalej: MRiRR), sygn. 1385, Sprawozdanie z akcji przeciwpowodziowej Wojewódzkiego Komitetu Przeciwpowodziowego m. st. Warszawy, [1947], k. nlb.

${ }^{29}$ Tamże, Protokół z posiedzenia Głównego Komitetu Przeciwpowodziowego, 26 XI 1946, k. nlb. 


\section{Straty}

Po fali mrozów i opadów śniegu nadeszły powodzie w całej Europie. Polska prasa informowała o ich wyjątkowo dużych, nienotowanych od kilkudziesięciu lat rozmiarach w Wielkiej Brytanii i Czechosłowacji ${ }^{30}$. Najtragiczniejsze informacje dochodziły jednak znad Odry. Przerwanie wałów po stronie niemieckiej w miejscowości Kietz (przed II wojna światową dzielnica Küstrina - obecnie Kostrzyna nad Odra) w Brandenburgii spowodowało ogromny i gwałtowny wylew. Z jednej strony uchronił on od powodzi tereny leżące po polskiej stronie Odry, z drugiej - był tragedia dla tego niemieckiego miasteczka, w którym miało utonać ponad 280 osób ${ }^{31}$.

Jaki jest polski rachunek strat powodziowych?

Szacowano, że uszkodzenia wałów i zatory spowodowały zalanie około 350 gromad, z czego w powiecie sochaczewskim zostało kompletnie zniszczonych 76 wsi, a w warszawskim -26 . Powódź dotknęła około 150 tys. osób, z czego w samym powiecie sochaczewskim straciły cały dobytek 13103 osoby, w pow. warszawskim - 8400 osób. Duże zniszczenia odnotowano również w województwie poznańskim (powiaty turecki, kolski i koniński: około 100 zalanych miejscowości). Według ówczesnych niejednoznacznych szacunków zalanych zostało około 46-52 tys. ha użytków rolnych oraz 50-73 tys. ha łąk i pastwisk. Ponadto utonęło blisko 2 tys. sztuk inwentarza żywego ${ }^{32}$. Powódź nie ominęła miast: pod wodą znalazł się w całości Nowy Dwór, Koło, część Konina i Poznania ${ }^{33}$.

${ }^{30}$ [b.a.], Zimno, śnieg $i$ wylewy rzek zdezorganizowaty transport $w$ Wielkiej Brytanii, „Głos Ludu” 1947, nr 75; [b.a.], Polska daje dowody przyjaźni. Dar dla powodzian $w$ Czechostowacji, „Głos Ludu” 1947, nr 75.

${ }^{31}$ AAN, MZO, sygn. 211 (mkf. B-5315), Sprawozdanie sytuacyjne wojewody szczecińskiego za maj 1947, k. 7; [b.a.], Wody Odry zalaty niemieckie miasteczko, „Dziennik Bałtycki” 1947, nr 83.

${ }^{32}$ AAN, CUP, sygn. 390, Sprawozdanie o sytuacji gospodarczej w Polsce, marzec 1947, k. 60; [b.a.], 25 mostów drogowych i 5 kolejowych zniszczyty wezbrane wody. Wywiad z wicem. Żaruk-Michalskim, „Życie Warszawy” 1947, nr 94; AAN, MPiOS, sygn. 271, Sprawozdanie ze skutków powodzi wiosennej 1947 r. i akcji pomocy do 17 IV 1947 r., k. 77-80; AAN, Kancelaria Cywilna Prezydenta RP i Kancelaria Rady Państwa (dalej: KCP), sygn. 301, Protokół III plenarnego posiedzenia WRN województwa warszawskiego 10 V 1947 w Sali ZZK w Pruszkowie, k. nlb.

${ }^{33}$ [b.a.], Nowy Dwór - miasto pod woda. Co ma powódź do polityki, „Głos Ludu” 1947, nr 86; [b.a.], Dramatyczna walka z szalejacym żywiołem, „Wola Ludu” 1947, $\mathrm{nr} 72$; [b.a.], $1.300 \mathrm{~km}$ nad Wista, Warta $i$ Odra. Szczecin jeszcze w okowach lodu, „Życie Warszawy” 1947, nr 87; [b.a.], Katastrofalna powódź w Europie obejmuje coraz większe obszary, „Głos Wielkopolski” 1947, nr 84; [b.a.], Odra ruszyła pod Kostrzyniem, „Kurier Szczeciński” 1947, nr 78. 
Do gospodarczych kosztów powodzi zaliczyć trzeba nie tylko zalane pola uprawne, zatopiony inwentarz żywy, ale również zniszczone lub uszkodzone mosty kolejowe i drogowe oraz domy i zabudowania gospodarcze. Według sprawozdania Sekcji Technicznej Głównego Komitetu Przeciwpowodziowego z 14 IV 1947 r. z ogólnej liczby 177 zagrożonych powodzia prowizorycznych mostów kolejowych zostało zniszczonych pięć (w tym dwa na Wiśle: w Warszawie pod Cytadela i w Toruniu, jeden na Bugo-Narwi w Nowym Dworze i dwa na Sanie: w Przemyślu oraz pod Munina), a uszkodzonych dalszych siedem. Ponadto poważniejszemu uszkodzeniu lub zniszczeniu uległo 26 mostów drogowych (m.in. na Wiśle w Warszawie, Puławach, Wyszogrodzie i Tczewie) ${ }^{34}$. Według szacunków Centralnego Urzędu Planowania straty w mostach kolejowych i drogowych wyrządzone przez powódź wyniosły ponad $600 \mathrm{mln}$ zł, a sama walka o nie kosztowała około $150 \mathrm{mln} \mathrm{zł}^{35}$. Straty w budynkach (na wsi i w mieście) w sierpniu $1947 \mathrm{r}$. szacowano na $188900480 \mathrm{zt}^{36}$.

Uszkodzenie i zerwanie mostów miało negatywny wpływ na telekomunikację. „Trybuna Robotnicza” z 22 III 1947 r. informowała, że z powodu towarzyszących mu uszkodzeń kabli - „telefoniczna komunikacja została zerwana niemal w całym kraju. Połaczenie telefoniczne istnieje jeszcze tylko między Łodzią i Poznaniem, lecz zachodzi obawa, że i te linie zostaną uszkodzone. Również komunikacja telefoniczna z zagranica na skutek uszkodzenia mostów została zerwana" ${ }^{37}$.

Minister obrony narodowej Michał Żymierski w piśmie do ministra pracy i opieki społecznej Kazimierza Rusinka wyliczał, że w okresie powodzi wojsko broniło 304 mostów, zużyło 317987 kg materiałów

${ }^{34}$ AAN, MPiOS, sygn. 271, Główny Komitet Przeciwpowodziowy, Sekcja Techniczna, Sprawozdanie techniczne z przebiegu powodzi wiosennej 1947 roku, Warszawa, 14 IV 1947, k. 66 n. Nieco inne dane zob. [b.a.], 25 mostów...; W. Balcerski, dz. cyt., s. 47.

${ }^{35}$ AAN, CUP, sygn. 390, Sprawozdanie o sytuacji gospodarczej w Polsce, marzec 1947, k. 62 .

${ }^{36}$ AAN, MPiOS, sygn. 271, Wykaz strat poniesionych w budynkach [powódź wiosenna 1947], k. 113. Co ciekawe, największe straty w budynkach wiejskich odnotowano w województwie śląsko-dąbrowskim (1360 zagród), a nie na terenach, gdzie powódź objęła rozległe tereny, jak w województwach warszawskim (347) i poznańskim (542). Straty ogółem w budynkach (na wsi i w mieście) były największe w województwach: warszawskim (78 864 tys. zł), śląsko-dąbrowskim (68 000 tys.), poznańskim (33 855 tys.), krakowskim (4130 tys.) i pomorskim (1315 tys.). Straty powodziowe w budynkach miejskich, poza pojedynczymi w województwach: gdańskim i pomorskim, odnotowano jedynie w warszawskim (92) i poznańskim (46).

${ }^{37}$ [b.a.], Groźna sytuacja na Wiśle. Szereg wsi pod woda, „Trybuna Robotnicza” $1947, \mathrm{nr} 81$. 
budowlanych, odbyło 142 loty samolotami, które zrzuciły 504 bomby ${ }^{38}$. Ogólny szacunek strat powodziowych, przedstawiony przez ministra Rusinka w trakcie jego wizyty w Poznaniu 27 marca, wynosił około 5 mld zł ${ }^{39}$. W samej komunikacji straty owe szacowano na około $1 \mathrm{mld} \mathrm{z}^{40}$.

Najtragiczniejsza pozycja w bilansie strat spowodowanych przez powódź to ofiary śmiertelne. Informacje na ten temat nie sa dokładne, ale jednak pozwalaja na dokonanie szacunku. W wywiadzie udzielonym „Życiu Warszawy” na początku kwietnia 1947 r. wiceminister administracji publicznej Aleksander Żaruk-Michalski twierdził, że 66 osób uznano za zaginione ${ }^{41}$. Informacja ta najpewniej dotyczyła cywilnych ofiar powodzi; wiadomo również, że w trakcie akcji przeciwpowodziowej zabitych zostało czterech żołnierzy, utonęło pięciu (głównie saperzy), a ośmiu odniosło rany ${ }^{42}$. Najwięcej ludzi zginęło na zalanych terenach województwa warszawskiego (55), a wojewoda wrocławski w informacji przedstawionej Ministerstwu Ziem Odzyskanych (MZO) wymieniał siedem osób, które uległy wypadkom śmiertelnym w czasie powodzi ${ }^{43}$. Za jej ofiary należy uznać również trzech pracowników Służby Ochrony Kolei; auto, którym się poruszali w okolicach mostów kolejowych na Odrze pod Szczecinem, zostało omyłkowo zbombardowane przez samoloty zrzucające ładunki na pokrywę lodowa ${ }^{44}$. Z zebranych danych (najpewniej niekompletnych) wynika, że liczba śmiertelnych ofiar powodzi oscylowała między 65 a 75 . Było to więcej niż w uznawanej dotychczas za najtragiczniejsza w XX w. w Polsce powodzi z 1934 r., która pochłonęła 55 ofiar $^{45}$.

${ }^{38}$ AAN, MPiOS, sygn. 271, Minister obrony narodowej Michał Żymierski do przewodniczaceego Nadzwyczajnej Komisji Rządowej dla Ofiar Powodzie, ministra pracy i opieki społecznej Kazimierza Rusinka [1947], k. 100.

39 [b.a.], Poprawa sytuacji powodziowej, „Wola Ludu” 1947, nr 75.

${ }^{40}$ W. Balcerski, dz. cyt., s. 48.

${ }^{41}$ [b.a.], 25 mostów...

${ }^{42}$ AAN, MPiOS, sygn. 271, Minister obrony narodowej Michał Żymierski do przewodniczącego Nadzwyczajnej Komisji Rządowej dla Ofiar Powodzi, ministra pracy i opieki społecznej Kazimierza Rusinka [1947], k. 100. Wg informacji „Głosu Wielkopolskiego” (1947, nr 89) w czasie walki o mosty i akcji ratowniczej utonęło 5 saperów, 3 zostało zabitych i 4 rannych.

${ }^{43}$ AAN, MZO, sygn. 349 (mkf. B-5453), Wojewoda wrocławski A. Barchacz MZO, Departament Administracji Publicznej, Wrocław, 6 VI 1947.

${ }^{44}$ AAN, MZO, sygn. 349 (mkf. B-5453), Wojewoda szczeciński do MZO, Szczecin, 25 III 1947, k. 218.

${ }^{45}$ [b.a.], Zarys monografii powodzi w Polsce w 40-lecie Gtównego Komitetu Przeciwpowodziowego, Warszawa 1988, s. 11. 


\section{Niecodzienne sytuacje, codzienna egzystencja}

Podstawowe źródło informacji na temat warunków życia na terenach zalanych stanowi ówczesna prasa. W Nowym Dworze, według korespondencji zamieszczonej w „Głosie Ludu” z 28 III 1947 r., „domy wyrastaja wprost z wody, na każdym wisi drabinka. Bo ludność Nowego Dworu nie ewakuowała się - zostali wszyscy nawet wtedy, kiedy trzeba było siedzieć na dachu - dziś to już jest w porównaniu z tymi dniami sielanka”. Komunikacja w mieście odbywała się za pomoca łódek i pontonów. Zdarzały się próby grabieży opuszczonych domów - stąd zapewne brała się niechęć do ewakuacji ${ }^{46}$. W zamieszczonym w „Gazecie Ludowej” 23 marca reportażu z terenów powodziowych w okolicach Sochaczewa pisano, że ludzie, zaskoczeni powodzia, ledwie uratowali życie, oblegali szczyty domów, woda bowiem podchodziła pod dachy.

„Wśród ludności, osaczonej przez wodę we wsiach gm. Głusk rozgrywają się dantejskie sceny. Ludzie szaleją z przerażenia i z trwogi o los swych najbliższych, z którymi rozłączyła ich woda, a o których nie wiedza, czy żyja. W pierwszych dniach rozlegał się ryk topiącego się bydła, usiłującego się ratować. Z samolotu obserwowano ludzi, płynacych wśród krzyku do Puszczy Kampinoskiej. Nie wszyscy dopłynęli”" ${ }^{4}$.

W Wyszogrodzie „zaobserwowano pływające trupy” ${ }^{48}$. Ta sama gazeta informowała, że na owych terenach: „Niejednokrotnie śmierć spotkała całe rodziny pograżone we śnie. Grozę powodzi powiększały olbrzymie zwały lodów, które miażdżyły nie tylko domostwa, ale i drzewa". Ludzie z tych okolic ratowali się ucieczką na strychy, dachy i kominy domów, w miare jak spiętrzała się fala wzburzonej wody. Na ucieczkę nie było czasu. Olbrzymia większość inwentarza żywego padła ofiara fali ${ }^{49}$. W Kazuniu Polskim - jak informowało „Życie Warszawy” - jedynymi budynkami niezalanymi były kościół i plebania. Tam zgromadziła się ludność, której pomocy udzielił ksiądz Tadeusz Kazimierski ${ }^{50}$. W innej korespondencji pisano o tym, jak spokojna dotychczas rzeka Wilanówka zalała wszystkie gospodarstwa we wsi Zawady. Miejscowa ludność

${ }^{46}$ [b.a.], Nowy Dwór - miasto pod woda...

${ }^{47}$ [b.a.], Dantejskie sceny na terenach powodziowych. 8 tysięcy ludzi na dachach domów, „Gazeta Ludowa” 1947, nr 81.

${ }^{48}$ Tamże.

49 [b.a.], Wista zmienita koryto. 40 wsi pod woda, 20 tysięcy ludzi bez dachu. Od specjalnego wystannika "Gazety Ludowej", „Gazeta Ludowa” 1947, nr 83.

${ }^{50}$ [b.a.], Wśród powodzian na zalanych terenach. Żotnierze zdejmuja ludność z kominów i dachów, „Życie Warszawy” 1947, nr 83. 
ratowała ptactwo i świnie, umieszczając je na strychach domostw: niestety nie było to możliwe w przypadku krów ${ }^{51}$.

Motyw ludzi koczujących na „wyspach” gruntów wystających z wody oraz na dachach domów, czekających na ratunek, pojawiał się w wielu innych publikacjach prasowych dotyczacych zalanych okolic Warszawy. Dużo mniej alarmistyczne tony można odnaleźć w publicystyce dotyczącej powodzi w innych regionach $\mathrm{kraju}^{52}$. Mimo niechęci, wywołanej strachem przed grabieżami dobytku, część powodzian musiała być ewakuowana; wedle doniesień prasowych ich liczba szacowana była na około 13 tys. w Sochaczewskiem i około 2,5 tys. w Poznańskiem ${ }^{53}$. Dużo miejsca poświęcano w prasie również omówionej już wcześniej walce o utrzymanie mostów ${ }^{54}$.

\section{Formy pomocy powodzianom}

Walkę ze skutkami anomalii pogodowych prowadziły przede wszystkim instytucje państwowe i organizacje społeczne.

${ }^{51}$ [b.a.], Potężny napór wody na wały wiślane. Wilanówka zalała Zawady. Pod Kazuniem fala powodzi rozszerza sie, ,Życie Warszawy” 1947, nr 82.

${ }^{52}$ Zob. m.in.: [b.a.], Niebezpieczeństwo epidemii $w$ zwiazku z powodzia, „Wola Ludu” 1947, nr 74; [b.a.], Czy minęło niebezpieczeństwo powodzi?, „Wola Ludu” 1947, nr 71; [b.a.], Wojsko, MO i ORMO w akcji przeciwpowodziowej. Mosty na Odrze $w$ porzqdku. W ciqgu najbliższych dni druga kulminacja $w$ Warszawie, „Głos Ludu” 1947, nr 75; [b.a.], Powódź w czasie mrozów. Groźne wylewy Warty i Noteci, „Gazeta Ludowa" 1947, nr 13.

${ }^{53} \mathrm{M}$. Gr., $Z$ transportem żywności dla powodzian. Sprawozdanie wystannika „Gazety Ludowej”, „Gazeta Ludowa” 1947, nr 88; [b.a.], Sytuacja w powiecie sochaczewskim. 76 wiosek objętych powodzia. Ponad 13 tysięcy ewakuowanych. Akcja ratownicza i organizacja pomocy, „Głos Ludu” 1947, nr 85.

${ }^{54}$ Zob. m.in.: [b.a.], Dwa mosty zerwane $w$ Warszawie. Poziom Wisty przekroczyt 5 m, „Gazeta Ludowa” 1947, nr 79; [b.a.], Saperzy walcza z kra na Warcie, „Wola Ludu” 1947, nr 65; Czy minęto niebezpieczeństwo powodzi?, „Wola Ludu” 1947, nr 71; [b.a.], Lody ruszyty na południu. Fala znosi mosty $i$ zalewa drogi. W Warszawie tymczasem Wisła opada, „Głos Ludu” 1947, nr 67; [b.a.], Lody ruszyty na wszystkich rzekach. Most Grunwaldzki we Wrocławiu zabezpieczony, „Głos Ludu” 1947, nr 79; [b.a.], Zniszczenie mostów prowizorycznych nie może wptynać na sprawność komunikacji. Co odbudować: most wysokowodny czy Ślaski?, „Głos Ludu” 1947, nr 80; [b.a.], Prowizoryczny most kolejowy $w$ Toruniu zniesiony przez kre, „Głos Ludu” 1947, nr 83; [b.a.], Dwa mosty $w$ Warszawie - zniesione. Samoloty i saperzy rozbili zatory pod Góra Kalwaria i pod Modlinem, „Robotnik” 1947, nr 78. O tym, jak w praktyce odbywało się kruszenie lodów, świadczy następujący fragment artykułu Walka z kra lodowa trwa w „Głosie Wielkopolskim” (1947, nr 75): „Saper z ładunkiem w ręku biegnie wzdłuż biegu rzeki za upatrzona kra. W odpowiednim momencie ciska ładunek w krę, odbiegając zarazem jak najdalej od brzegu. W górę, przy wtórze wybuchu wzbija się fontanna wody oraz lodowych odprysków". 
Pomoc powodzianom początkowo miała formę doraźną. W celu jej koordynacji 24 III 1947 r. powołana została Nadzwyczajna Komisja Rządowa Niesienia Pomocy Ofiarom Powodzi (NKR). Tego samego dnia Prezydium Rady Ministrów upoważniło Ministerstwo Pracy i Opieki Społecznej do otwarcia kredytu na cele pomocy ofiarom powodzi w wysokości $100 \mathrm{mln}$ zł. Pod przewodnictwem Bolesława Bieruta ukonstytuował się 1 kwietnia Centralny Komitet Obywatelski Pomocy Ofiarom Powodzi (CKO), działajacy w porozumieniu z Nadzwyczajna Komisja Rządowa, której wszyscy członkowie weszli w skład Prezydium Centralnego Komitetu. W posiedzeniu inauguracyjnym wzięli udział m.in. premier Józef Cyrankiewicz i kardynał Adam Sapieha (obaj zostali zastępcami przewodniczącego Komitetu). Wszystkie prace i zarządzenia NKR podlegały akceptacji prezydenta. Przewodnictwo NKR zostało powierzone ministrowi pracy i opieki społecznej, ponadto weszli do niej wiceministrowie administracji i rolnictwa. Utworzono specjalne konto w PKO, na które miały być przekazywane wszystkie ofiary ze zbiórek organizacji społecznych i politycznych ${ }^{55}$.

W'śód urzędów państwowych pomocy poszkodowanym przez żywioł udzieliły przede wszystkim resorty: zdrowia i obrony narodowej. Ten pierwszy wysłał na tereny zalane ekipy sanitarne i dezynfekcyjne. Zajmowały się one m.in. chlorowaniem wody w celu jej odkażenia i szczepieniami ochronnymi ${ }^{56}$.

Wojsko zorganizowało ewakuację ludności z zalanych terenów. W ten sposób wywieziono 3910 osób, 574 sztuki bydła i nierogacizny. Ewakuowanych z zatopionych terenów województwa warszawskiego umieszczono m.in. w koszarach 2. Pułku Saperów, w forcie VIII we wsi Grochale Stare, w Grochalach Górnych, w kościele we wsi Leoncin, na wzgórzu Wincentówek, we wsi Gniewniewice (180 osób) ${ }^{57}$.

${ }^{55}$ AAN, MPiOS, sygn. 271, Sprawozdanie ze skutków powodzi wiosennej $1947 \mathrm{r}$. i akcji pomocy do 17 IV 1947 r., k. 77 i n.; [b.a.], Centralny Komitet Obywatelski Pomocy Ofiarom Powodzi, „Gazeta Ludowa” 1947, nr 92; [b.a.], Powołanie Nadzwyczajnej Komisji Rzqdowej Pomocy dla Ofiar Powodzi, „Głos Ludu” 1947, nr 83; [b.a.], Pomoc powodzianom - to obowiqzek narodowy, „Chłopska Droga” 1947, nr 15; [b.a.], Rzqd i społeczeństwo organizuja pomoc dla powodzian, „Głos Wielkopolski” 1947, nr 93.

${ }^{56}$ AAN, Ministerstwo Zdrowia, sygn. 2/17, Sprawozdanie z działalności Ministerstwa Zdrowia za II kwartał 1947, k. 10.

${ }^{57}$ AAN, Urząd Rady Ministrów (dalej: URM), sygn. 2/35, Biuletyn Nadzwyczajnej Komisji Rządowej Niesienia Pomocy Ofiarom Powodzi, Warszawa nr 5, 1 IV 1947, k. 34; AAN, MPiOS, sygn. 271, Minister obrony narodowej Michał Żymierski do przewodniczącego Nadzwyczajnej Komisji Rządowej dla Ofiar Powodzie, ministra pracy i opieki społecznej Kazimierza Rusinka [1947], k. 100. 
$\mathrm{Z}$ organizacji społecznych największą rolę $\mathrm{w}$ akcji niesienia pomocy doraźnej dla powodzian odegrały Polski Czerwony Krzyż (PCK), Centralny Komitet Opieki Społecznej (CKOS) i Caritas. Jak wynika z danych dotyczących okresu do 17 IV 1947 r., PCK opiekował się zdrowiem powodzian; ewakuował 2251 osób, przewiózł 1200 chorych. Rozdzielono 27000 sztuk odzieży i obuwia. W tym samym czasie Caritas rozdał $2352 \mathrm{~kg}$ żywności oraz odzież i obuwie. YMCA ofiarowała $1060 \mathrm{~kg}$ mleka w proszku i $520 \mathrm{~kg} \mathrm{kakao}^{58}$.

CKOS był tą instytucja społeczna, której na podstawie uchwały Rady Ministrów z 19 IX 1946 r. zlecono organizowanie tzw. akcji pomocy zimowej; 12 III 1947 r., z powodu przeciagania się mrozów oraz powodzi, przedłużono ją do 30 kwietnia. W sprawozdaniu z działalności w 1947 r. władze Komitetu stwierdzały, że w momencie klęski jego placówki pospieszyły z pomoca doraźna. Wydano dla dotkniętych żywiołem około 54 tys. posiłków, 250 ton żywności, 7700 szt. odzieży i 2600 szt. naczyń kuchennych ${ }^{59}$. Niektóre kuchnie polowe dla powodzian (m.in. w Legionowie, Zakroczymiu i Nowym Dworze) funkcjonowały w dzień i w nocy ${ }^{60}$.

Odnalezione informacje źródłowe świadcza, że do akcji pomocy przystapiły również inne niż wymienione organizacje społeczne, działające wówczas w Polsce. 2 kwietnia w ramach NKR został powołany Centralny Komitet Młodzieży Pomocy dla Powodzian, który obją najważniejsze organizacje młodzieżowe działające w Polsce - dla zbiórki na rzecz powodzian w całym kraju ${ }^{61}$.

Pomocy ofiarom żywiołu udzielały również zagraniczne organizacje charytatywne. Jako jedni z pierwszych ofiarnością wykazali się kwakrzy, deklarując 4200 kg żywności, leków i odzieży, następnie przedstawiciele Szwedzkiej Pomocy Europie, którzy ofiarowali 800 sztuk odzieży i JOINT, który zadeklarował 39 ton żywności, leków i odzieży ${ }^{62}$. W maju 1947 r. do poszkodowanych w gminach powiatu warszawskiego dotarły transporty darów Rady Polonii Amerykańskiej. 19 IV 1947 r. „Robotnik” informował, że Duński Komitet Pomocy Dzieciom „Red-Barnet”

${ }^{58}$ AAN, URM, sygn. 2/35, Biuletyn Nadzwyczajnej Komisji Rządowej Niesienia Pomocy Ofiarom Powodzi, Warszawa, 31 III 1947, nr 4, k. 28.

${ }^{59}$ AAN, CKOS, sygn. 199, Dane o działalności organizacji za okres sprawozdawczy od 1 I do 31 XII 1947 r., k. 21.

${ }^{60}$ AAN, URM, sygn. 2/35, Biuletyn Nadzwyczajnej Komisji Rządowej Niesienia Pomocy Ofiarom Powodzi, Warszawa, 31 III 1947, nr 4, k. 28.

${ }^{61}$ AAN, MPiOS, sygn. 271, Sprawozdanie ze skutków powodzi wiosennej $1947 \mathrm{r}$. i akcji pomocy do 17 IV 1947 r., k. 77 n.

${ }^{62}$ Tamże; AAN, URM, sygn. 2/35, Biuletyn Nadzwyczajnej Komisji Rządowej Niesienia Pomocy Ofiarom Powodzi, Warszawa, 27 III 1947, nr 1, k. 10. 
i Duński Czerwony Krzyż podjęły się wyżywienia całej ludności powiatu sochaczewskiego dotkniętej powodzią i „dostarczenia pewnej ilości żywności na inne tereny powodziowe"63.

Dostarczenie jej nie zawsze było zdaniem prostym. Czasami, wobec trudności dotarcia na otoczone przez rozlaną wodę tereny, konieczne było zrzucanie worków z żywnością z samolotów. Tak było m.in. w okolicach Zakroczymia pod koniec marca ${ }^{64}$.

Ponadto prasa informowała, że Zjednoczenie Zrzeszeń Rodzicielskich zgłosiło gotowość natychmiastowego przyjęcia dzieci z ewakuowanych terenów do domu turnusowego w Świdrze. Wydział Wczasów m. Warszawy oddał dla nich swój dom w Szklarskiej Porębie. Dom Don Suisse w Otwocku i dom Szwedzkiego Czerwonego Krzyża w Dzierżążnie zarezerwowano wyłącznie dla dzieci powodzian ${ }^{65}$.

Wysiłek społeczeństwa w akcji przeciwpowodziowej ilustruje suma 92928 412,49 zł, która wpłynęła na konto powodziowe NKR od 28 marca do 21 kwietnia od instytucji, przedsiębiorstw prywatnych i państwowych, związków zawodowych, rad zakładowych i indywidualnych ofiarodawców, nie licząc ofiar w naturze i gotówce, które samorzutnie gromadzone były przez społeczeństwo od pierwszego dnia alarmu przeciwpowodziowego i dostarczane bezpośrednio na tereny dotknięte klęska ${ }^{66}$.

W ówczesnej prasie można znaleźć wiele informacji o wyjątkowej i spontanicznej ofiarności społecznej osób prywatnych, grup zawodowych czy pracowników zakładów pracy, okazywanej powodzianom. „Głos Ludu” 12 IV 1947 r. zapewniał, że „największą ofiarność, tak jak dotychczas, wykazuje znów świat pracy”. Jako potwierdzenie tej opinii pisano, że załoga kopalni „Anna” zebrała 150 tys. zł, a „robotnicza Łódź” - 1200 tys. $z^{67}$. W dzienniku KC PPR drukowano listy datków pieniężnych zakładów pracy, pisano o ofiarach sochaczewskich piekarzy i rzeźników w postaci chleba i kiełbasy ${ }^{68}$. Apele i prośby o pomoc oraz informacje o jej udzielaniu ukazywały się również

${ }^{63}$ [b.a.], Powodzianie spod Sochaczewa pod opieka Duńskiego Czerwonego Krzyża, „Robotnik” 1947, nr 105.

${ }^{64}$ AAN, URM, sygn. 2/35, Biuletyn Nadzwyczajnej Komisji Rządowej Niesienia Pomocy Ofiarom Powodzi, Warszawa, 28 III 1947, nr 2, k. 14.

${ }^{65}$ [b.a.], Organizacja pomocy dla dzieci powodzian. Udziat instytucji polskich i zagranicznych, „Głos Ludu” 1947, nr 85.

${ }^{66}$ AAN, MPiOS, sygn. 271, Sprawozdanie ze skutków powodzi wiosennej $1947 \mathrm{r}$. i akcji pomocy do 17 IV 1947 r., k. 77 n.

${ }^{67}$ [b.a.], Apel pomocy trwa. Świat pracy dokonat wielkiego wysitku, ale potrzebny jest jeszcze większy, „Głos Ludu” 1947, nr 99.

${ }^{68}$ [b.a.], Społeczeństwo odpowiada na apel. Zbiorki pieniężne na rzecz powodzian, „Głos Ludu” 1947, nr 85. 
w innych tytułach prasowych. Zwracali się o nią także przedstawiciele lokalnych władz ${ }^{69}$.

W tym wyliczeniu form bezpośredniej pomocy dla powodzian wypada wskazać również nieliczne odnalezione wzmianki o wyjatkowej ofiarności indywidualnej $\mathrm{w}$ akcji przeciwpowodziowej. W ówczesnej prasie jako wzór takiej bezinteresownej postawy przedstawiano Marka Cichego, który na zalanych terenach Sochaczewskiego „na swej łodzi łupince uratował 70 ludzi"70. Wojewoda wrocławski w piśmie do MZO wymieniał nazwiska tych, którzy stracili życie w trakcie powodzi. Część z nich, sądząc z lakonicznych wzmianek, zginęła w walce z żywiołem ${ }^{71}$.

Ofiarność jednostek i doraźna pomoc nie mogły jednak trwale rozwiązać najważniejszych problemów ludzi poszkodowanych przez powódź. Potrzeby znacznie przewyższały otrzymane wsparcie. W celu uzyskania większych środków CKO podjął uchwałę o jednorazowym przeznaczeniu na ten cel 1/4 sumy uiszczonej tytułem Daniny Narodowej na zagospodarowanie Ziem Odzyskanych albo kwoty należnej z tego tytułu od płatników podatku obrotowego i podatku od nieruchomości. Płatnicy podatku gruntowego w naturze zostali opodatkowani w ilości $5 \mathrm{~kg}$ żyta od każdego hektara z gruntów użytkowanych, od których wymierzono im Daninę. Osoby osiągajace wynagrodzenia za pracę lub z tytułu służby publicznej miały płacić na rzecz powodzian sumy w wysokości określonej uchwałami związków zawodowych. Dobrowolne ofiary na rzecz powodzian mogły być zarachowane na poczet

${ }^{69}$ Zob. m.in.: [b.a.], Potrzeba natychmiastowej pomocy. Odezwa PSL do chłopów. Do wszystkich członków i sympatyków PSL województwa warszawskiego - Zarzqd Wojewódzki PSL $w$ Warszawie, „Gazeta Ludowa” 1947, nr 83; AAN, MAP, sygn. 59 (mkf. B-750), Sprawozdanie sytuacyjne kwartalne wojewody kieleckiego za okres od 1 I do 31 III 1947, k. 10; AAN, URM, sygn. 2/35, Biuletyn Nadzwyczajnej Komisji Rządowej Niesienia Pomocy Ofiarom Powodzi, Warszawa, 31 III 1947, nr 4, k. 26-28.

${ }^{70}$ [b.a.], Sytuacja w powiecie sochaczewskim. 76 wiosek objętych powodzia. Ponad 13 tysięcy ewakuowanych. Akcja ratownicza i organizacja pomocy, „Głos Ludu” 1947, nr 85.

${ }^{71}$ Byli to: Adam Żak, lat 32, ślusarz (utoną przy odsuwaniu kry od mostu na rzece Barycz między Żmigrodem a Żmigródkiem); Jan Susul, ślusarz z gromady Wierzbna gm. Jaworzyna Ślaska (utonał w czasie likwidowania zatoru lodowego); Tadeusz Zajęcki, były Komendant Straży Pożarnej Fabryki Papieru w Pieńsku, i Leopold Herbst, starszy strażak Zawodowej Straży Pożarnej w Zgorzelcu (obaj utonęli przy rozbijaniu kry na Nysie Łużyckiej); Stefan Rosiak z Pieńska (utoną 14 marca podczas ratowania mostu rurociagowego na rzece Czerwona Woda, Zgorzelec Ujazd). Zob. AAN, MZO, sygn. 349 (mkf. B-5453), Wojewoda wrocławski A. Barchacz, MZO, Departament Administracji Publicznej, Wrocław, 6 VI 1947, k. 42. 
powyższych norm, a składki na rzecz powodzian miały być wpłacone w całości w ciagu kwietnia ${ }^{72}$.

Jakie były efekty przyjętych rozwiązań? Ogólną informację na ten temat zawiera protokół z posiedzenia ścisłego Prezydium CKO z 18 VII 1947 r. Wiktor Kościński, sekretarz Komitetu, podsekretarz stanu w Ministerstwie Skarbu, przedstawił wyniki zbiórki pieniężnej na rzecz powodzian. Do 17 lipca zebrano 751614232 zł. Stanowiło to $60 \%$ wymiaru gotówkowego jednorazowego świadczenia na rzecz ofiar powodzi. Kościński twierdził, że ofiarność chłopów na rzecz powodzian „nie zawsze była na właściwym poziomie”. Do 20 czerwca dostarczono na ich rzecz $3115560 \mathrm{~kg}$ żyta, $41240 \mathrm{~kg}$ pszenicy, $498359 \mathrm{~kg}$ jęczmienia i $10850 \mathrm{~kg}$ mąki żytniej ${ }^{73}$. Jak wynika z tych danych, pomoc zaoferowana powodzianom tylko w niewielkiej części rekompensowała ich straty.

Dylemat o znaczeniu podstawowym, który musiał być rozstrzygnięty przez władze państwowe zajmujące się skutkami powodzi i pomocą dla ich ofiar, dotyczył sensowności odbudowy zagród wiejskich na terenach zalewowych w województwie warszawskim. Przekonanie, że na tych terenach nie opłaca się inwestować i nie ma pieniędzy na ich odpowiednie obwałowanie ${ }^{74}$ legło u podstaw pomysłu przesiedlenia mieszkańców na tzw. Ziemie Odzyskane. Pomysł nie spotkał się z powszechną akceptacją samych zainteresowanych ${ }^{75}$.

Mimo to działająca przy Prezydium Warszawskiej Wojewódzkiej Rady Narodowej Delegatura WRN do spraw przesiedleńczych zbadała odpowiednie gospodarstwa w województwie olsztyńskim. Przesiedlanie, aczkolwiek niewolne od trudności (wielokrotne przerzucanie niektórych osadników z miejsca na miejsce, praktyki korupcyjne lokalnych władz), zostało wcielone w życie. 30 kwietnia wyjechał pierwszy transport, złożony z 79 rodzin (303 osoby), z gmin Głusk i Kampinos do Czerwonki Mazurskiej w pow. Reszel ${ }^{76}$. Jeszcze w maju dla przesiedlajacych się przygotowano gospodarstwa w powiatach: braniewskim, reszelskim, bartoszyckim (woj. olsztyńskie) i elbląskim (woj. gdańskie).

72 [b.a.], Centralny Komitet Obywatelski Pomocy Ofiarom Powodzi, „Gazeta Ludowa" 1947, nr 92.

${ }^{73}$ AAN, URM, sygn. 5/788, Protokół z posiedzenia ścisłego Prezydium Centralnego Komitetu Obywatelskiego Pomocy Ofiarom Powodzi na czele z przewodniczącym prezesem RM Józefem Cyrankiewiczem 18 VII 1947, k. 6.

${ }^{74}$ Zbawienne wyjście $w$ przesiedleniu. Ojcowie żyli $w$ nędzy, synowie moga mieć dobrobyt, „Gazeta Ludowa” 1947, nr 130.

${ }^{75}$ AAN, URM, sygn. 5/788, List do premiera, 10 VI 1947, k. 11.

${ }^{76}$ AAN, MPiOS, sygn. 271, Sprawozdanie ze skutków powodzi wiosennej $1947 \mathrm{r}$. i akcji pomocy do 17 IV $1947 \mathrm{r}$. 
Kolejne transporty dotarły na miejsce przeznaczenia w maju i czerwcu. Dla wyjeżdżających kupowano konie i krowy, wyposażono ich w zapas żywności ${ }^{77}$. Ogółem, według danych Ministerstwa Pracy i Opieki Społecznej, w 1947 r. przeniosło się na nowe miejsca 714 rodzin z pow. warszawskiego i sochaczewskiego ${ }^{78}$.

\section{Próby politycznej instrumentalizacji powodzi}

Analiza przekazów zdaje się świadczyć, że powódź była również okazja dla propagandowego zinstrumentalizowania wyrazów troski i pomocy ze strony rządzących. Już 21 III 1947 r. wszystkie najważniejsze gazety informowały o pojawieniu się Bolesława Bieruta poprzedniego dnia w okolicach zniesionego mostu wysokowodnego w Warszawie ${ }^{79}$. Prasa pisała też o dokonanej przez niego i towarzyszące osoby (m.in. premier Józef Cyrankiewicz, minister pracy i opieki społecznej Kazimierz Rusinek, wiceminister obrony narodowej gen. Marian Spychalski) wizytacji terenów dotkniętych powodzią wzdłuż Wisły 24 marca $^{80}$. Taką ,gospodarską wizytę” na terenach powodziowych w Poznańskiem złożył kilka dni później minister Kazimierz Rusinek ${ }^{81}$.

Drobne akcenty o znaczeniu politycznym pojawiają się również $\mathrm{w}$ doniesieniach prasowych gazet peperowskich, gdzie oprócz informacji o „przodownictwie” „klasy robotniczej” w dziele pomocy dla powodzian wskazywano na datki przekazane przez lokalne komitety partyjne PPR, Urzędy Bezpieczeństwa, przedstawicieli władz ${ }^{82}$. „Głos Ludu” piętnował również rzekome wypadki „dorabiania się” na nieszczęściu ze strony lokalnych działaczy Polskiego Stronnictwa Ludowego z Nowego Dworu. Podczas gdy „towarzysze peperowcy” z narażeniem życia za

77 AAN, CKOS, sygn. 199, Dane o działalności organizacji za okres sprawozdawczy od 1 I do 31 XII 1947, k. 21.

${ }^{78}$ AAN, MPiOS, sygn. 263, Opieka społeczna 1944-1947, s. 83.

${ }^{79}$ Zob. m.in.: [b.a.], Prezydent Bierut na miejscu katastrofy informowat się o dalszej akcji obronnej, „Głos Ludu” 1947, nr 79; [b.a.], Dwa mosty w Warszawie - zniesione. Samoloty i saperzy rozbili zatory pod Góra Kalwariq i pod Modlinem, „Robotnik” 1947, nr 78.

${ }^{80}$ [b.a.], Wszyscy na pomoc powodzianom. Prezydent Bierut o rozmiarach katastrofy $i$ środkach do walki z jej skutkami. Najważniejsza akcja w obecnej chwili, „Głos Ludu” 1947, nr 83.

${ }^{81}$ [b.a.], Poprawa sytuacji powodziowej, „Wola Ludu”1947, nr 75.

82 [b.a.], Apel pomocy trwa. Świat pracy dokonat wielkiego wysitku, ale potrzebny jest jeszcze większy, „Głos Ludu” 1947, nr 99; [b.a.], Robotnik ślaski spieszy z pomoca, „Trybuna Robotnicza” 1947, nr 88. 
darmo ratowali ludzi, peeselowiec Józef T. został aresztowany, bo od wołających o pomoc ludzi zażądał 1,5 tys. zł za przewóz ${ }^{83}$.

Wydaje się jednak, że tendencja „instrumentalizacyjna” miała znaczenie drugorzędne. Dominowało przekonanie o konieczności udzielenia pomocy bez względu na to, z jakich źródeł ona pochodzi. Zbiórki na powodzian były dokonywane przez organizacje społeczne, redakcje czasopism, partie wszystkich kierunków politycznych.

Nastroje owej solidarności w nieszczęściu najlepiej oddaje następujacy fragment przemówienia Stefana Brzezińskiego, wojewody poznańskiego, zamieszczony w „Biuletynie Nadzwyczajnej Komisji Rządowej Niesienia Pomocy Ofiarom Powodzi”: „nie podobna jest mówić o czyjejkolwiek winie, niezaradności czy nieudolności. Wykluczona jest rzecza, aby ktoś ośmielił się kuć kapitał polityczny z tragicznego bilansu strat i zniszczeń. Jedyna postawa słuszna, jaką każdy z nas może i winien zając wobec sytuacji wytworzonej na dużych obszarach naszego kraju jest postawą pełnej solidarności”.

O odwrócenie takich jak ta klęsk - mówił wojewoda - często zanosimy modły w hymnach kościelnych ${ }^{84}$.

$$
* \quad * \quad *
$$

Chociaż przedstawione uwagi na temat powodzi moga stanowić jedynie wstęp do dalszych badań, to wskazuja, że jest ona niesłusznie zapomnianym wydarzeniem, które wpłynęło na losy wielu dziesiątków ludzi. Emocje i zachowania ofiar żywiołu, skuteczność i sposób działania służb państwowych i instytucji społecznych powołanych do udzielania im pomocy i walki ze skutkami klęsk elementarnych tego typu - to tylko niektóre problemy, które warto poddać dogłębnej analizie. Może się wszak okazać, że na wielkich obszarach Polski o jakości życia ich mieszkańców nie decydowała tylko wielka polityka, ale - czasami przede wszystkim - „wielka woda”.

${ }^{83}$ [b.a.], Nowy Dwór - miasto pod woda...

${ }^{84}$ AAN, URM, sygn. 2/35, Biuletyn Nadzwyczajnej Komisji Rządowej Niesienia Pomocy Ofiarom Powodzi, Warszawa, 31 III 1947, nr 4, k. 26. Zob. też S. Brzeziński, wojewoda poznański, W chwili ciężkiej próby, „Głos Wielkopolski” 1947, nr 88. 
Dariusz Jarosz

Grzegorz Miernik

The flood of 1947: from studies on the contexts of natural disasters in Poland after World War II

(Summary)

In the article the author has attempted to characterize certain contexts of the 1947 flood - one of the worst calamities in Poland in the 20th century. According to incomplete data, at least 65 people died as a result, which is more than in the 1934 flood, which until then had been considered the worst (with 55 victims).

The discussion, based mainly on source materials which have not been used before and press articles, relates to issues such as: anomalous weather conditions in Poland and Europe in the years 1946-47 (a cold wave), reasons for the flood (climate-related, organizational, economic), loss of property, everyday life in areas struck by the calamity and attempts at its political objectification, and forms of aid for the victims.

Key w ords: flood, natural disasters, climate anomalies, cold weather 